\title{
Irmáos do Rosário e sectários da religião maometana: sociabilidades entre africanos no Recife oitocentista
}

Valéria Gomes Costa*

\section{RESUMO}

Este artigo analisa as conexóes religiosas entre africanos libertos que transitavam entre a Irmandade do Rosário dos Pretos de Santo Antônio e o culto islâmico no Recife do século XIX. Para os africanos que viveram as experiências de escravidão e de liberdade no Brasil, o pertencimento a mais de uma comunidade religiosa era relevante para assegurar seus arranjos políticos e sociais ou mesmo garantir a manutenção de sua cultura. Este foi o caso de algumas pessoas cujas trajetórias estão vinculadas ao Recife escravista. A proposta dessa discussão é abordar as conexóes entre práticas e saberes de religióes africanas em meio ao catolicismo. As principais fontes de pesquisa foram testamentos e inventários post-mortem, jornais e registros paroquiais, que foram analisadas sob as lentes da microanálise italiana.

Palavras-chave: africanos muçulmanos; conexóes religiosas; Recife; século XIX.

\section{ABSTRACT}

This article analyzes the religious connections among freed Africans, who were followers of the brotherhood of Rosário dos Pretos de Santo Antônio and of Islam in Recife during the nineteenth century. For Africans who had experienced slavery and freedom in Brazil, belonging to more than one religious community was relevant in order to assure social and political arrangements, or even to maintain their culture. This was the case of some people whose trajectories are linked to the city of Recife before the abolition of slavery. The goal of the discussion is to approach the links between the practices and knowledge of African religions in the midst of Catholicism. The main sources of the research were wills and post mortem inventories, newspapers and parish records, which were analyzed under the perspective of Italian microanalysis. Keywords: African Muslims; religious connections; Recife; nineteenth century.

\section{DOI: http://dx.doi.org/10.1590/2237-101X01903702}

Artigo recebido em 16 de fevereiro de 2016 e aprovado para a publicaçáo em 13 de setembro de 2017.

* Professora do Instituto Federal de Educação, Ciência e Tecnologia - Sertão de Pernambuco. E-mail: valeriaodecosta@gmail.com.

Agradeço aos membros da Linha de Pesquisa Escravidão e Invenção da Liberdade do programa de pós-graduação em História Social da UFBA, em particular ao Prof. Dr. João Reis, pelos comentários feitos a um texto preliminar; è̀ Prof. ${ }^{a}$ Dra. Solange Rocha da UFPB, que fez valorosas críticas à presente versão. 


\section{RESUMEN}

El artículo analiza las conexiones religiosas entre africanos liberados que transitaban entre la Hermandad del Rosario de los Negros de Santo Antonio y el culto islámico en el Recife durante el siglo XIX. Para los africanos que vivieron las experiencias de esclavitud y libertad en Brasil, la pertenencia a más de una comunidad religiosa era relevante para asegurar arreglos políticos y sociales, o incluso para garantizar la sobrevivencia de su cultura. Este fue el caso de algunas personas cuyas trayectorias están vinculadas al Recife esclavista. La propuesta de esa discusión es abordar las conexiones entre prácticas y saberes de religiones africanas en medio del catolicismo. Las principales fuentes de la investigación comprenden testamentos e inventarios post-mortem, periódicos y registros parroquiales, que fueron analizados bajo la perspectiva del microanálisis italiano.

Palabras clave: africanos musulmanes; conexiones religiosas; Recife; siglo XIX.

O presente trabalho não tem a pretensão de fazer uma análise das práticas religiosas e da religiosidade dos africanos libertos em si ou por si mesmas. Privilegiamos perquirir suas articulaçôes sociais e políticas, dentro e fora das instituiçôes, para a garantia de seus espaços na cidade. Isto é, os nexos tecidos entre os religiosos e suas negociaçôes para conviver com a religiáo hegemônica e as práticas dos cultos de origem africana que tiveram alguma continuidade no Brasil, ainda que adaptadas localmente. Para tanto, analisamos as vivências de homens e mulheres que criavam estratégias de sobrevivência em meio aos estigmas impostos pela sociedade escravista.

A historiografia acerca das experiências de ex-cativos no Brasil é bastante vasta, inclusive, em termos de método. Todavia, ainda é parco o conhecimento acerca dos universos rurais e urbanos da vida dos libertos africanos, cujas trajetórias estiveram vinculadas à província de Pernambuco. ${ }^{1}$ Revisitar, contudo, um tema bastante explorado pela historiografia tornou-se uma tarefa difícil. Quais questôes inovadoras, além de inserir Pernambuco nas discussôes, apareceriam? Almejando trazer para o debate as experiências dos africanos libertos no Recife, buscamos as peculiaridades dos indivíduos que formaram grupos sociais na luta pela afirmação de sua autonomia nos espaços citadinos. Nesse aspecto, surgiu (ou ressurgiu) o tema dos africa-

\footnotetext{
${ }^{1}$ Entre os diversos trabalhos acerca das experiências africanas nos espaços rurais e urbanos, cf. AMARAL, Sharise Piroupo do. Um pé calçado e outro no chão: liberdade e escravidão em Sergipe (Continguiba, 18601890). Salvador: Edufba, 2012; FARIAS, Juliana Barreto. Mercados minas: africanos ocidentais nas praças do Rio de Janeiro (1830-1890). Tese (doutorado em História Social) — Universidade de São Paulo, São Paulo, 2012; SCHANTZ, Ana Paula. Libertos no Rio Grande de São Pedro: Porto Alegre e Viamão no final do século XVIII e início do XIX. Dissertação (mestrado em História) — Universidade Federal da Bahia, Salvador, 2009; OLIVEIRA, Maria Inês Côrtes de. O liberto: seu mundo e os outros (1790-1890). Salvador: Corrupio, 1988.
} 
nos islamizados, cujo grande referencial são os estudos de João Reis. ${ }^{2}$ Mas, diferentemente de Reis, perscrutamos as redes políticas amistosas entre muçulmanos e católicos, até mesmo, de muçulmanos que se tornaram membros da mesa diretora da Irmandade do Rosário dos Pretos de Santo Antônio. Pierre Verger foi o primeiro a discutir possibilidades de harmonização entre o catolicismo e o islamismo, enfatizando as devidas distinçóes, chegando a afirmar, ademais, ser o fenômeno uma exclusividade baiana. ${ }^{3}$ Acreditamos ter avançado um pouco mais do que Verger, devido à amplitude da pesquisa documental de natureza serial, qualitativa e quantitativa que realizamos, a qual nos levou para além das narrativas testamentárias e nos permitiu destrinchar a complexidade das teias sociais, das disputas políticas e dos conflitos de poder nos espaços católicos e islâmicos frequentados pelos africanos, revisitando também o debate sobre a cidade do Recife como território de muçulmanos de origem africana no século XIX.

Para a composição dessas sociabilidades na comunidade africana, entre o catolicismo e o islamismo, utilizamos trinta testamentos e inventários post-mortem como fontes orientadoras das ligações nominativas no arcabouço documental. A ligação nominativa é uma das ferramentas da microanálise utilizada por vários historiadores, sendo Carlo Ginzburg uma das grandes referências. $\mathrm{O}$ nome traduz mais do que indicaçáo de lugares, objetos e pessoas; ele também enuncia as açóes dos sujeitos, servindo de significante e significado. Pode, além disso, dar-nos pistas de caminhos que percorremos na vastidão das fontes a serviço da recuperação de histórias. Para Ginzburg, buscar nas fontes o nome de alguém possibilita-nos reconstruir os enredos sociais em que os indivíduos estiveram inseridos. Os nomes das pessoas que faziam parte dos grupos negros evidenciados neste trabalho foram o nosso "fio de Ariadne" a nos guiar no labirinto dos acervos documentais. ${ }^{4}$

A seleção desses trinta testamentos - em meio ao nosso corpus documental - baseou-se, a princípio, em três razóes. Primeiro, por serem os testadores africanos de procedência da Costa Ocidental da África. Embora tenha sido Pernambuco, depois do Rio de Janeiro, a região onde desembarcou o maior número de africanos procedentes de Angola e do Congo, há de se admitir que os ocidentais, em particular o reduzido número de "minas", também deixaram suas marcas e falares evidenciados na região, sobressaíram na criação de mecanismos para assegurar seus espaços sociais no Recife. Por diversas vezes, em disputas no seio da comunidade negra, os "minas" levavam vantagem, como, por exemplo, nos conflitos dentro das irmandades negras, dos quais trata-

\footnotetext{
${ }^{2}$ Cf. REIS, João José. Rebelião escrava no Brasil: a história do levante dos malês em 1835. Ed. rev. ampl. São Paulo: Companhia das Letras, 2003.

${ }^{3}$ Cf. VERGER, Pierre. Os libertos: sete caminhos na liberdade de escravos da Bahia, no século XIX. Salvador: Corrupio, 1992, p. 39-41.

${ }^{4}$ Nosso arsenal documental abarcou, além dos testamentos e inventários post-mortem, registros paroquiais, notas cartoriais, circulares policiais e da Casa de Detenção, processos criminais e cíveis, livros de confrarias religiosas, jornais, entre outros periódicos, como o Almanack Pernambucano. Sobre o método da ligação nominativa, cf. GINZBURG, Carlo. Mitos, emblemas e sinais: morfologia e história. Sáo Paulo: Companhia das Letras, 1989.
} 
remos mais adiante. Segundo, esses indivíduos juntamente com seus familiares, parentes e amigos, transitavam entre o catolicismo e o islamismo - universos religiosos intransigentes e exclusivos. Terceiro, os testamentos foram produzidos, entre as décadas de 1860 e 1890, no momento em que as práticas religiosas africanas estavam litigando espaços de legitimidade na capital da província pernambucana. As discussões aqui elencadas, enfim, se inserem no debate sobre as conexões entre práticas e saberes de religióes africanas no meio do catolicismo. 5

\section{Reinventando práticas mortuárias na diáspora}

No Brasil, as celebraçóes fúnebres dos africanos se transformaram em reunióes de naçôes, além de se constituírem em ocasião para escravizados e libertos relembrarem suas religiôes tradicionais. Por meio dos registros de testamentos, em particular, da escolha de seus testamenteiros, cotejamos estratégias na manutenção das práticas religiosas de suas terras. Comumente, esses indivíduos primavam por nomear como testamenteiros seus patrícios e, sempre que possível, pessoas de sua nação. Sírio Manoel Ribeiro Taques era liberto da Costa d'África, talhador de carne verde e morador do bairro de São José. Solteiro, era pai de uma filha, cuja mãe, Maria da Conceição, também era africana. Declarou em seu testamento que deixava seu enterro para ser feito "à vontade de seus testadores". A princípio, nada além do costume de testar, não fosse o fato de que Sírio Manoel era muçulmano. Em 1873, ano em que elaborou seu testamento, participou intimamente da mobilizaçấo de um grupo de africanos para adquirir licença de prática do islamismo na cidade, como apresentaremos mais adiante. Seu primeiro testamenteiro, o mina Alexandre Rodrigues d'Almeida, era seu patrício que ficou encarregado de realizar suas últimas vontades. ${ }^{6}$ Por sua vez, o mina Alexandre escolheu para realizar seu enterro seus patrícios Policarpo Ramos de Jesus e Jovino Lopes Ferreira. Este muçulmano e aquele católico. ${ }^{7}$

Cláudia Rodrigues, João Reis e Mariza Soares, entre outros estudiosos, trouxeram para o debate como as agremiaçôes católicas agenciavam os funerais dos indivíduos. ${ }^{8}$ No caso par-

\footnotetext{
5 Entre alguns estudiosos dedicados ao tema, ver CALAINHO, Daniela. Metrópole das mandingas: religiosidade negra e inquisição portuguesa no Antigo Regime. Rio de Janeiro: Garamond, 2008; XAVIER, Regina Celia Lima. Religiosidade e escravidáo no século XIX: mestre Tito. Porto Alegre: Editora da UFRGS, 2008; SOARES, Mariza. Devotos da cor: identidade étnica, religiosidade e escravidáo no Rio de Janeiro, século XVIII. Rio de Janeiro: Civilização Brasileira, 2000.

${ }^{6}$ Memorial de Justiça de Pernambuco (MJPE), mapoteca 13, Gaveta F, LRT (1871-1873), Testamento de Sírio Manoel Ribeiro Taques, fl. 3-3v. Sobre a utilização de testamentos para perscrutar a cultura mortuária de africanos, cf. SOARES, Mariza. Devotos da cor: identidade étnica, religiosidade e escravidão no Rio de Janeiro, século XVIII, op. cit., p. 153.

${ }^{7}$ Cf. Inventário de Alexandre d'Almeida.

${ }^{8}$ RODRIGUES, Cláudia. Lugares dos mortos na cidade dos vivos: tradiçóes e transformaçóes fúnebres no Rio de Janeiro. Rio de Janeiro: Secretaria Municipal de Cultura, 1999; REIS, João José. A morte é uma festa:
} 
ticular dos africanos, Maria Inês de Oliveira discutiu como o silêncio era utilizado enquanto tática para assegurar os anseios religiosos, objetivando ter o sepultamento conforme sua cultura original. Oliveira cogitou, ainda, que os libertos africanos na Bahia (predominantemente da África Ocidental) foram os mais cônscios quanto às estratégias para a manutenção de sua identidade cultural. ${ }^{?}$

Importante item no enxoval fúnebre era a roupa do enterramento. No pequeno universo de trinta testamentos, rastreamos dezessete pessoas para analisar a escolha de seus hábitos. $\mathrm{O}$ carmelita representou 41,1\%; o lençol ou camisão branco e o beneditino, cada um, 23,5\%; o franciscano, $11,5 \%$. Reis, Soares, Rodrigues e Oliveira mostraram que a mortalha branca era a única opção para os indivíduos sem condiçôes de enterrarem-se com hábitos dos santos de devoçãoo. ${ }^{10}$ Escravos, forros e homens livres pobres, negros e brancos, desde o período colonial, enterravam-se com o hábito branco. Como se vê, os africanos não eram os únicos que associavam a cor branca à morte. Para os cristãos, o branco simbolizava a alegria da vida eterna, prometida por meio da ressurreição, sendo também a cor da bem-aventurança. ${ }^{11} \mathrm{~A}$ mortalha ainda refletia as condiçôes socioeconômicas dos indivíduos. A branca, em especial, a de algodáozinho, era a mais barata. No caso das pessoas que acompanhamos, sugerimos — como fizeram Oliveira e Reis — que a opção por essa cor mortuária talvez estivesse relacionada com as tradiçôes religiosas, visto que suas situaçóes econômicas eram privilegiadas em comparaçáo à grande maioria dos ex-cativos. Ainda sobre os rituais de enterramento dos africanos no Recife, Vanessa Sial cogitou que em espaços privados, como o interior de igrejas, os indivíduos gozavam de certa liberdade para manifestação de suas crenças. Para ela, isso talvez propiciasse encenaçôes de cerimoniais fúnebres de tradição africana. ${ }^{12}$

Quanto aos santos de devoção, sempre mencionados nos testamentos, registramos aqueles mais mencionados pelas pessoas que estabeleceram vínculos com a comunidade muçulmana. Afora Sáo Benedito $(53,3 \%)$ e № S $^{a}$ do Rosário (43,3\%), foram citados, também, a

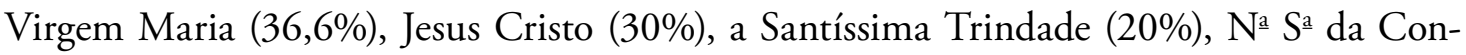
ceição (6,6\%), entre outros, com pequena participação: Santo Onofre, São Francisco, Santo Antônio, São João, São Sebastião, São João Batista e Santa Luzia. Embora, entre os africanos que perscrutamos, Sáo Benedito tenha apresentado mais devotos, os estudos da escravidão

ritos fúnebres e revolta popular no Brasil no século XIX. São Paulo: Companhia das Letras, 1991; SOARES, Mariza. Devotos da cor: identidade étnica, religiosidade e escravidão no Rio de Janeiro, século XVIII, op. cit. ${ }^{9}$ Cf. OLIVEIRA, Maria Inês Côrtes de. O liberto: seu mundo e os outros (1790-1890), op. cit., p. 89.

${ }^{10}$ Cf. REIS, João José. A morte é uma festa: ritos fúnebres e revolta popular no Brasil no século XIX, op. cit., p. 116-127; SOARES, Mariza. Devotos da cor: identidade étnica, religiosidade e escravidão no Rio de Janeiro, século XVIII, op. cit., p. 174-178; 180-188; RODRIGUES, Cláudia. Lugares dos mortos na cidade dos vivos: tradiçôes e transformaçóes fúnebres no Rio de Janeiro, op. cit.; OLIVEIRA, Maria Inês Côrtes de. O liberto: seu mundo e os outros (1790-1890), op. cit., p. 74-102.

${ }^{11}$ Cf. REIS, João José. A morte é uma festa: ritos fúnebres e revolta popular no Brasil no século XIX, op. cit., p. 118 e 124.

${ }^{12}$ Cf. SIAL, Vanessa de Castro. Das igrejas ao cemitério: políticas públicas sobre a morte no Recife no século XIX. Recife: Fundação de Cultura Cidade do Recife, 2007, p. 187. 
apontaram que a Senhora do Rosário era a principal devoção — desde o século XVI — da população negra, nomeando os primeiros e cardinais oragos de irmandades de pretos e pardos no Brasil escravista. ${ }^{13}$

\section{Confrarias religiosas como espaços de sociabilidade e conflito}

Os estudos sobre as irmandades católicas negras há muito vêm demonstrando a relevância desses espaços de sociabilidades africanas na diáspora, sobretudo na América portuguesa. A documentação produzida por essas instituiçôes torna-se bastante fértil para acessarmos o conhecimento sobre a organizaçáo social, administrativa e a história de fundação. Alguns pesquisadores valeram-se dos documentos produzidos pelas confrarias para vislumbrar litígios entre seus membros. ${ }^{14}$ Para Nicolau Parés, a consagrada literatura ainda é insuficiente para sabermos quem eram os indivíduos que integravam essas agremiações e seus perfis étnicos. Ele analisou os perfis dos africanos filiados a essas agremiaçôes católicas, recompondo seus vínculos de parentesco, afetivos, de negócios, de trabalho, vislumbrando o papel das irmandades no processo de sociabilidades dos sujeitos. ${ }^{15}$ Estivemos, no entanto, interessados nas relaçôes sociais entre mesários do Rosário e muçulmanos. Portanto, passaremos, agora, às análises sobre as agremiaçôes mais procuradas pelos africanos minas que perscrutamos, a partir da amostra dos testamentos, no universo documental pesquisado.

No Recife do século XIX, no meio da população negra, além das irmandades do Rosário, as mais populares foram as de São Benedito, Jesus Maria José, № Sa da Saúde, Senhor

${ }^{13}$ Cf.: REGINALDO, Lucilene. Os rosários dos angolas: irmandades de africanos e crioulos na Bahia setecentista. São Paulo: Alameda, 2011, p. 54-55.

${ }^{14}$ Entre a vasta literatura sobre irmandades negras cito: DELFINO, Leonara Lacerda. $O$ rosário dos irmãos escravos e libertos: fronteiras, identidades e representaçôes do viver e morrer na diáspora atlântica. Tese (doutorado em História) — Universidade Federal de Juiz de Fora, Juiz de Fora, 2015. PARÉS, Nicolau Luís. Milicianos, barbeiros numa irmandade católica de africanos minas e jejes (Bahia, 1770-1830). Tempo, Rio de Janeiro, v. 20, p. 1-32, 2014. REGINALDO, Lucilene. Os rosários dos angolas: irmandades de africanos e crioulos na Bahia setecentista, op. cit.; MAC CORD, Marcelo. O rosário de D. Antônio: irmandades negras, alianças e conflitos na história social do Recife 1848-1872. Recife: Edufpe, 2008; SOARES, Mariza. Devotos da cor: identidade étnica, religiosidade e escravidão no Rio de Janeiro, século XVIII, op. cit.; QUINTÃO, Antônia. Lá vem meu parente: as irmandades de pretos e pardos no Rio de Janeiro e Pernambuco (século XVIII). São Paulo: Annablume, 2002; ASSIS, Virgínea M. Almoêdo de. Pretos e brancos: a serviço de uma identidade de dominação (o caso das irmandades do Recife). Dissertaçáo (mestrado em História) Universidade Federal de Pernambuco, Recife, 1998. REIS, João José. Identidade e diversidade étnica nas irmandades negras no tempo da escravidão. Tempo, Rio de Janeiro, v. 2, n. 3, p. 199-242, 1997.

${ }^{15}$ Parés, por meio do método da ligação nominativa, construiu perfis étnicos, laços de parentesco, afetivos, de trabalho e comerciais, estabelecidos entre os africanos filiados à Irmandade do Bom Jesus das Necessidades e da Redenção, na Bahia. Cf. PARÉS, Nicolau Luís. Milicianos, barbeiros numa irmandade católica de africanos minas e jejes (Bahia, 1770-1830), op. cit. 
Bom Jesus dos Martírios e Na $S^{a}$ do Livramento. ${ }^{16}$ Como nosso interesse estava nos trinta testadores que transitavam entre o catolicismo e o islamismo, privilegiamos apenas o intervalo de tempo correspondente à atuação desses testadores, seus parentes e amigos nas agremiaçóes, obtendo o resultado apresentado na Tabela 1.

Tabela 1: Irmandades citadas nos testamentos de africanos libertos entre 1846-1890

\begin{tabular}{|c|c|c|c|}
\hline Irmandades & \multicolumn{3}{|c|}{ Número de citaçóes } \\
\hline & Homens & Mulheres & Total \\
\hline Rosário dos Pretos de Santo Antônio & 4 & 4 & 8 \\
\hline Rosário dos Pretos da Boa Vista & - & 4 & 4 \\
\hline São Benedito & 5 & 10 & 15 \\
\hline Jesus Maria José & 3 & 5 & 8 \\
\hline São Cristóvão & 1 & - & 1 \\
\hline Santa Agonia & - & 1 & 1 \\
\hline Total & 13 & 24 & 37 \\
\hline
\end{tabular}

Fonte: MJPE, Testamentos (1849-1853; 1854-1856; 1860-1869; 1871-1877); IPHAN-PE, Livro de Registro de Eleiçôes (1833-1858) da Irmandade do Rosário dos Pretos de Santo Antônio, cx. 21; ACBJR, Livro de Óbitos, 1890-1891.

Nesse reduzido universo, a Irmandade de São Benedito surgiu como a mais popular, com quinze indicações. O número de mulheres, aliás, representou o dobro do de homens, mas é relevante destacar que a maioria delas entrava acompanhada de seus respectivos maridos. Essa superioridade numérica feminina, também nas demais confrarias, deveu-se, em parte, ao fato de serem as mulheres maioria no grupo de testadores. Sua participação era de $60 \%$, enquanto representavam $65 \%$ dos que eram membros de confrarias católicas. Levantamos a hipótese de que, no século XIX, elas passaram a ocupar com mais ênfase os espaços religiosos públicos. Entre 1835 e 1853, foi registrada uma média de 742 novos membros na Irmandade do Rosário de Santo Antônio, dentre os quais $56 \%$ eram do sexo feminino. ${ }^{17}$

Wlamyra Albuquerque apontou a popularidade de São Benedito no sul da Bahia na década de 1880, em especial, entre os negros, mostrando como era marcante a presença das irmandades negras nas procissóes de devoção ao santo. ${ }^{18}$ Nesse pequeno universo dos testadores com que trabalhamos, a Irmandade de São Benedito apareceu como a mais procurada pelas pessoas

${ }^{16}$ Cf. ARAÚJO, Clara. Governadores das naçóes e das corporaçôes: cultura política e hierarquias de cor em Pernambuco (1776-1817). Dissertação (mestrado em História) — Universidade Federal Fluminense, Niterói, 2007, p. 49.

${ }^{17}$ IPHAN-PE, Livro Suplementário das Entradas dos Irmãos e Irmãs ou Livro de Registro de Irmãos, 18351853. Cx. 23.

${ }^{18}$ Cf. ALBUQUERQUE, Wlamyra. O jogo da dissimulação: abolição e cidadania negra no Brasil. São Paulo: Companhia das Letras, 2009, p. 134-137. 
de origem africana, inclusive, da Costa da Mina. Mas, ao que parece, na hora dos arranjos políticos, o grupo circunscrito privilegiava estreitar laços políticos com vogais da Irmandade do Rosário dos Pretos de Santo Antônio, ${ }^{19}$ como apresentaremos adiante. Essa confraria, juntamente com a de Jesus Maria José, foi a segunda mais indicada pelos testadores.

Em Pernambuco, a Irmandade do Rosário dos Pretos foi fundada em 1654, provavelmente na Igreja de São Frei Pedro Mártir, no bairro do Recife. A igreja, no bairro de Santo Antônio, foi construída na segunda metade do século XVII, pois em 1686 o culto religioso já estava em funcionamento. Na província, era a mais imponente das confrarias negras. Marcelo Mac Cord, citando Patrícia Mulvey, informa que, das vinte irmandades de negros criadas no período colonial pernambucano, doze eram do Rosário. ${ }^{20}$

Tendo em vista serem as irmandades sob a invocação do Rosário as mais imponentes dentre as agremiaçóes negras de Pernambuco, inferimos que seu espaço se tornou cenário de grandes tensóes e conflitos entre africanos de diversas naçóes e crioulos. Por meio de seus compromissos, é possível vislumbrar como se organizavam internamente; como seus membros deveriam se portar dentro e fora dela; e as dissidências e alianças entre os confrades, particularmente, angolas e minas. Os compromissos de 1758 e 1870 do Rosário de Santo Antônio e o de 1862 do Rosário da Boa Vista servem como guias. Esses estatutos revelam, além dos pactos, as querelas que permeavam essas instituiçóes, a partir das discussóes sobre legalidade, fiscalização e obediência da regra confraternal. ${ }^{21}$

No compromisso de 1870 do Rosário de Santo Antônio, ficaram visíveis as restriçôes socioeconômicas, enquanto desapareceu a ordem de privilégios entre negros africanos e brasileiros: "será indispensável na mesa regedora a mistura de africanos e nacionais sob pena de nulidade da mesa." 22 Já o compromisso de 1862 do Rosário da Boa Vista apresenta certa equidade racial nas hierarquias da agremiação: "haverá duas juízas pretas, a saber uma por eleição e outra por devoção e da mesma forma duas escrivãs e mais doze mordomas", ${ }^{23}$ e "também haverá juízes e escrivães brancos de ambos os sexos na forma do artigo antecedente". ${ }^{24}$ Ou seja, em meados do Oitocentos, as Irmandades do Rosário dos Pretos deixavam de ser um espaço de privilégios dos homens negros.

A supremacia numérica dos angolas na província refletia-se na Irmandade do Rosário. Os crioulos, filhos dos africanos, associaram-se aos angolas. Esse fenômeno também foi descrito por João Reis e Lucilene Reginaldo para a Bahia. ${ }^{25}$ Outros grupos de procedência,

\footnotetext{
${ }^{19}$ Vogal é aquele que tem voto nas comunidades, juntas etc. No caso das agremiações católicas, eram aqueles ocupantes de cargos na mesa diretora.

${ }^{20}$ Cf. MAC CORD, Marcelo. O rosário de D. Antônio: irmandades negras, alianças e conflitos na história social do Recife 1848-1872, op. cit., p. 37.

${ }^{21}$ Ibidem, p. 75.

${ }^{22}$ Arquivo Público Estadual Jordão Emereciano (APEJE), AE, Compromisso do Rosário dos Pretos de Santo Antônio, Cap. 6, art. 50, fl. 567v.

${ }^{23}$ APEJE, AE, Compromisso do Rosário da Boa Vista, cap. 12: "Das disposiçôes gerais”, art. 53, fl. 318v.

${ }^{24}$ Ibidem, art. 54, fl. 318v.

${ }^{25}$ Cf. REIS, Identidade e diversidade étnica nas irmandades negras no tempo da escravidão, op. cit.;
} 
especialmente da Costa da Mina, subordinaram-se aos angolas e crioulos. Porém, os minas também procuravam irmandades nas quais o acesso às esferas de poder fosse mais factível, mesmo que tivessem de se associar aos crioulos, como os angolas faziam nas Irmandades do Rosário. Nas eleiçóes para a mesa da Irmandade do Patriarca Sáo Domingos dos Homens Pretos eram escolhidos doze mordomos, sendo oito minas e quatro crioulos. Não tivemos acesso aos compromissos dessas irmandades, mas foi possível verificar que, na hierarquia da mesa, os pretos minas estabeleceram políticas de domínio semelhantes às dos angolas, no Rosário dos Pretos de Santo Antônio, no século XVIII. Para Clara Araújo, o fato de serem cerceados aos minas a precedência e os postos mais altos nas hierarquias do Rosário fez com que eles criassem estratégias de organização não só em outras Irmandades, mas também nas esferas civis, como nas governanças de pretos (organizaçóes das corporações de ofícios no século XVIII). Citamos, como exemplo, as patentes de governadores dos canoeiros e das pretas boceteiras, outorgadas pelo governo colonial aos indivíduos da Costa da Mina. ${ }^{26}$

Afora as divergências entre minas e angolas na hierarquia da mesa regedora, outros atritos entre nações ocorreram dentro das Irmandades do Rosário. Mac Cord discutiu as desavenças, na década de 1840, entre os minas e d. Antônio de Oliveira Guimarães, rei do Congo, de nação angola, instituído como representante de todas as naçôes reunidas na Irmandade do Rosário de Santo Antônio. Em 1848, às vésperas da Revolução Praieira, os minas aliaram-se aos liberais do partido praieiro, indo de encontro às determinaçóes de $\mathrm{d}$. Antônio, que apoiou os conservadores. Ou seja, a figura de d. Antônio como líder de todas as naçôes era contestada pelos próprios africanos que estavam sob sua regência. ${ }^{27}$

\section{O Rosário dos Pretos de Santo Antônio: um espaço africano}

REGINALDO, Lucilene. Os rosários dos angolas: irmandades de africanos e crioulos na Bahia setecentista, op. cit.

${ }^{26}$ Cf. ARAÚJO, Clara. Governadores das naçôes e das corporaçôes, op. cit., p. 93. Mac Cord afirma ser o maracatu, na esfera extramuros da irmandade, um instrumento de criação mina para fazer frente aos cortejos angolas nas irmandades. Cf. MAC CORD, Marcelo. O rosário de D. Antônio: irmandades negras, alianças e conflitos na história social do Recife 1848-1872, op. cit., p. 135. Desde o alvorecer do século XX que os maracatus sáo divididos em dois grupos. O primeiro, chamado de naçáo, caracteriza-se pelos cortejos urbanos ao som de alfaias (como são chamados os tambores dos maracatus em Pernambuco), gonguês e caixas de guerra. O segundo, denominado rural, diferencia-se dos primeiros pela indumentária e composição dos personagens, sobretudo com a presença do caboclo de lança (homenagem ao trabalhador canavieiro). Sua orquestra é composta por instrumentos de sopro. Para mais informaçōes, consultar GUERRA PEIXE, Cesar. Maracatus do Recife. Recife: Prefeitura da Cidade do Recife, 1980. Mariza Soares argumentou que os africanos da Costa da Mina, excluídos das esferas da irmandade do Rosário, criavam as próprias agremiaçóes. Cf. SOARES, Mariza. Devotos da cor. In: MAC CORD, Marcelo. O rosário de D. Antônio: irmandades negras, alianças e conflitos na história social do Recife 1848-1872, op. cit., p. 135.

${ }^{27}$ Ibidem, p. 130-135. 
Embora o compromisso de 1870 ofusque as origens dos seus membros, ao cruzar os nomes de alguns mesários que encontramos nos livros da irmandade com outros documentos, deparamo-nos com africanos minas nas hierarquias da mesa. O preto da costa José Francisco da Costa foi tesoureiro e definidor. Nas eleiçóes de 1852, concorreu ao cargo de juiz com Benedito Joaquim de Souza e José Vicente, ficando em segundo lugar. O savalú Manoel Maxado exerceu também o cargo de tesoureiro em 1839. Contrariando a afirmativa de Mac Cord sobre a exclusividade angola e crioula na mesa do Rosário, mostramos, pelo cruzamento entre as atas do Rosário, testamentos e registros paroquiais, que é possível traçar um perfil étnico dos indivíduos e que os pretos da Costa da Mina também alcançaram as posiçôes mais altas da instituição. O poder de articulação dos minas dentro e fora da irmandade era tamanho que favoreceu a circularidade deles na hierarquia da mesa, exercendo os cargos mais importantes, como apresentaremos a partir das experiências de sociabilidades dos africanos cujas trajetórias acompanhamos.

Houve libertos que chegaram até a fazer carreira na Mesa do Rosário. A carreira na mesa, no entanto, dependia de alguns fatores - não só étnicos — como articulaçáo política, condiçáo econômica, jogos de interesses que perpassavam alianças e/ou cisóes entre os indivíduos. Rastreamos alguns sujeitos que exerceram diversos cargos, inclusive o de juiz, a exemplo dos minas Estevão José das Chagas, Felipe Nery, Felipe das Chagas Ferreira, Jacob Joaquim da Silva e Luiz de Milibú. Perquirindo essas pessoas, em diversos documentos, construímos o perfil de cada uma delas e suas conexôes dentro e fora da irmandade.

Comumente, uma mesa era formada por um juiz e seu respectivo vice, um secretário, um tesoureiro, um procurador geral, um zelador, três procuradores particulares e doze definidores. As eleições ocorriam a cada dois anos e os eleitos ocupavam os cargos durante um ano, podendo continuar no ano seguinte, mas em diferente cargo. Daí a ocorrência de circularidade de mesários em diversas funçôes. Para ser juiz, o indivíduo doava uma joia no valor de $20 \$ 000$. Cuidava do bom andamento da relaçáo com a igreja e os funcionários na prestação das contas da instituição. O secretário pagava $15 \$ 000$ e teria que ser alfabetizado e não possuir débitos com a confraria no ato da posse, competindo-lhe fazer todas as escrituraçôes e organizar os arquivos. O procurador-geral, cuja joia era no valor de $12 \$ 000$, fiscalizava todas as escrituraçôes e negócios da irmandade, dando pareceres das receitas e despesas da confraria. O tesoureiro encarregava-se dos livros de certidáo de missas, recibos, socorros dos membros e tudo quanto julgasse necessário e dissesse respeito às contas da irmandade. $\mathrm{O}$ procurador de patrimônio entrava com uma joia de $6 \$ 000$, cabendo-lhe a cobrança mensal dos aluguéis dos inquilinos de prédios da confraria. Os definidores pagavam uma joia de menor valor, $5 \$ 000$, e eram escolhidos pelo juiz. Tiravam esmolas para a festa da padroeira e outros eventos. O zelador, como o próprio nome diz, zelava pela fé dos irmáos. A importância dos vogais do Rosário, contudo, náo estava apenas na sua participaçáo na composiçáo da mesa administrativa da irmandade, mas, em particular, nas suas competências no plano 
social. Prestígio socioeconômico, saber ler e escrever, ter articulaçóes na comunidade, eram os atributos mais requisitados..$^{28}$

O mina Esteváo José das Chagas exerceu o cargo de definidor em 1839. Em 1861 apareceu como ex-procurador do Recife, sendo eleito juiz na gestão de 1867-1868 e reeleito para o biênio 1868-1869. Também exerceu a função de procurador do patrimônio e, em 1869, presidiu a Comissáo de Administraçáo no dia 3 de novembro, cujo objetivo era formular estratégias para pacificar as divergências no seio da hierarquia da irmandade. Sua atuação na instituição foi ímpar, sobretudo durante a Comissão, mas faleceu em 24 de fevereiro de 1870 , às vésperas da aprovação do novo compromisso da irmandade. Sua morte foi bastante lamentada pelos confrades. ${ }^{29}$ Estevão era também bem relacionado no meio da comunidade mina. Figurou como padrinho de crianças, filhas de seus patrícios, e adultos africanos. No dia 7 de setembro de 1834, ele levou à pia batismal dois rebentos de pretos forros: Bernardina, cujos pais, Francisco Lourenço e Joaquina Maria da Conceição Teixeira, eram naturais da Costa da Mina; Luiz, filho dos africanos libertos José Barreto e Benedicta de Costa. No dia 26 de setembro de 1848, foi a vez de Estevão apadrinhar a preta de naçáo Costa, Isabel. Além de batizar, ele também foi testamenteiro de outros minas, como Duarte José Martins da Costa, de nação savalú, marinheiro e pequeno traficante de escravos, morador do bairro de Santo Antônio; e da preta Rita de Souza, que era cega, e Joaquina da Conceição Araújo, comerciante, ambas moradoras do bairro de São José. ${ }^{30}$

O vogal Felipe Nery, liberto da Costa, morador no pátio do Livramento, bairro de Santo Antônio, associou-se ao Rosário dos Pretos no dia 6 de janeiro de 1838. Figurou como testamenteiro do savalú Duarte e da preta Rita de Souza. Nery iniciou sua trajetória como mesário na gestão de 1851-1852, no cargo de definidor. $\mathrm{Na}$ ata da eleição de 1857, apareceu como ex-escrivão, concorrendo à vaga de tesoureiro, e obteve 25 votos, ocupando o cargo no período de 1858-1859. Na gestão de 1860-1861 voltou a ser definidor, último cargo de que se tem notícias ter ele ocupado. ${ }^{31}$

O liberto Felipe das Chagas Ferreira, definidor durante a gestão de Estevão, morava no bairro do Recife e era casado com a africana Catharina Francisca da Silva. Assim

\footnotetext{
${ }^{28}$ Cf. COSTA, Valéria. Trajetórias negras: os libertos da Costa d'África no Recife, 1846-1890. Tese (doutorado em História Social) — Universidade Federal da Bahia, Salvador, 2013, p. 218.

${ }^{29}$ IPHAN-PE, Livros de Atas - Termos da Irmandade (1850-1871), séc. XIX, cx. 30, fl. 16-18v, 20, $22-$ 22v, 30-30v, 42v-74-74v; Livro de Registros de Eleiçóes (1833-1858), cx. 21, fl. 10. Mac Cord também traz informaçóes sobre a vida de Estevão José das Chagas, porém, por se restringir ao universo das atas da irmandade, não cruzando suas informaçôes com outros documentos, como fizemos, não conseguiu traçar seu perfil étnico e social. Cf. MAC CORD, Marcelo. O rosário de D. Antônio: irmandades negras, alianças e conflitos na história social do Recife 1848-1872, op. cit., p. 79-80.

${ }^{30}$ Arquivos da Matriz do Santíssimo Sacramento da Boa Vista (AMSSBV), LB 5 (18/01/1829 a 21/04/1832), Batizados da crioula Bernardina e do crioulo Luiz, fl. 17v-18; Arquivos da Cúria Metropolitana do Recife e Olinda (ACMRO), LB 25 (1848-51), batizado de Isabel, adulta, nação da Costa, fl. 17v; MJPE, Testamentos de Duarte José Martins da Costa, Rita de Souza e Joaquina da Conceição Araújo.

${ }^{31}$ IPHAN-PE, Livro de Registros de Eleições (1833-1858), cx. 21, fls. 3v, 4-4v, 5, 15-22v, 24, 28 e 29.
} 
como os outros irmáos do Rosário, ocupou alguns cargos a partir de 1861. Foi definidor, procurador do Recife e do patrimônio, concorreu às eleiçóes para juiz na gestão de 1862-1863, ficando em segundo lugar, com doze votos; mas assumiu a procuradoria geral do Recife. Assim como os demais vogais, também foi chamado para apadrinhar crianças e figurar como testamenteiro de outros libertos africanos. No dia 8 de maio de 1859, batizou na matriz do Corpo Santo o crioulo Justino, filho de africanos libertos. Em 1868 foi instituído como segundo testamenteiro de seu compadre, o cassange João Joaquim José de Sant'Anna, que era trabalhador no porto e "vivia de emprestar dinheiro a juros".

Já o irmão Jacob Joaquim da Silva, segundo testamenteiro do mina José Francisco da Costa, ex-mesário, a quem nos referimos alhures, iniciou sua carreira na gestão de 1847 1848, como procurador. Na década de 1850 foi definidor, depois tesoureiro, procurador do patrimônio e juiz. Embora tivesse alcançado o posto mais alto na mesa regedora, o de juiz, apresentava dificuldades para assegurar até a própria moradia. $\mathrm{Na}$ década de 1860, os problemas financeiros comprometeram o pagamento do aluguel da casa em que morava, propriedade da irmandade, na rua das Águas Verdes, tendo de entregá-la, pois além de não poder quitar as mensalidades, ficou sem condiçôes de realizar os reparos necessários na alvenaria. Decerto, esse era mais um dentre tantos casos de declínio social, processo pelo qual passaram vários libertos. Por outro lado, suas habilidades de "ler e escrever" lhe garantiam certo prestígio dentro e fora da irmandade. ${ }^{32}$

Luíz de Milibú era natural da Costa d'África. Assim como Estevão, também se destacou como mesário do Rosário. Foi definidor na década de 1830 e a partir de 1857 começou a ocupar cargos mais altos, como o de procurador do Recife. Concorreu às eleiçôes para juiz na gestáo de 1858-1859, mas só conseguiu ocupar a função no ano de 1861, quando venceu a disputa com Felipe das Chagas Ferreira. Foi tesoureiro por dois mandatos, sendo o último o de 1866-1867, quando deixou a tesouraria para se tornar zelador. Tudo indica que Luíz tinha familiares, parentes ou negócios fora da província. Em seu matrimônio teve os proclamas dispensados, para seguir — de imediato — viagem à Bahia com sua mulher. ${ }^{33}$

É relevante destacar também que os homens e as mulheres, na qualidade de mesários, não cuidavam só do funcionamento da confraria, organizando festas de padroeiros, procissóes, enterramentos, sufrágios e pedidos de acompanhamento da irmandade feitos pelos associados em seus testamentos. Acima de tudo, eles asseguravam que o patrimônio de seus membros não caísse em mãos indevidas, como, por exemplo, as de ex-senhores desejosos de tirar vantagens de seus ex-cativos. Procuravam, ainda, evitar que os bens de seus associados

\footnotetext{
${ }^{32}$ IPHAN-PE, Livros de Atas (1850-1871), fl. 3-5v, 8-19, 26; Livros de Eleição (1830-1858), fl. 17v; Mac Cord registra também a participação deste vogal (cf. MAC CORD, Marcelo. O rosário de D. Antônio: irmandades negras, alianças e conflitos na história social do Recife 1848-1872, op. cit., p. 92).

33 IPHAN-PE, Livros de Atas (1850-1871), fl. 17-42; ACMRO, Assento de casamento de Luiz de Milibú e Alexandrina Maria Ferreira, 23/06/1852, fl. 227v. Cf. COSTA, Valéria. Trajetórias negras: os libertos da Costa d’África no Recife, 1846-1890, op. cit., p. 221.
} 
sem familiares ou parentes fossem a leilão público. Enfim, promoviam intensas conexôes para além do espaço das agremiaçôes, dialogando com os africanos alheios a essas instituiçôes, possibilitando a ampliação de suas redes relacionais.

Essas relaçôes construídas pelos mesários do Rosário, para além da prática religiosa, podem ser compreendidas como espaços de domínio dos africanos na diáspora. Isto é, as alianças eram feitas ou reiteradas entre famílias, parentes e/ou indivíduos cujas experiências remetiam à origem africana e à passagem do cativeiro à liberdade. Havia mesários que se abrigaram sob o "guarda-chuva étnico" mina, e as pessoas com quem eles mantinham estreitos laços de amizades eram oriundas da Costa da Mina. A nação, contudo, aparece como um referencial pertinente, mas nem sempre decisivo. Existia, ainda, a possibilidade de que indivíduos de diferentes naçóes estabelecessem vínculos de amizade, negócios etc., dentro e fora do Rosário. Essa construçáo de espacialidade africana, por sua vez, deixa transparecer não só solidariedades, como também divergências e conflitos nas relações entre os indivíduos.

\section{Negros islamizados no Recife: entre práticas e saberes}

Para africanos e crioulos cujas experiências estavam atreladas à escravidão, pertencer a mais de uma comunidade religiosa era relevante para garantir seus arranjos sociais. Eram intensas as conexóes entre os libertos afluentes da cidade e os associados à Irmandade do Rosário, especialmente entre os minas. $\mathrm{O}$ mina Alexandre, sobre quem já comentamos, tinha entre seus principais amigos indivíduos que fizeram parte da mesa regedora do Rosário de Santo Antônio. Seu terceiro testamenteiro, Policarpo Ramos de Jesus, exerceu o cargo de definidor em 1869 e de tesoureiro em 1870. Porém, além das articulações e negociaçóes, ocorriam também tensóes e conflitos entre os membros das confrarias católicas e outros segmentos religiosos.

Em 1873, um grupo de africanos praticantes do islamismo entrou com o seguinte pedido de licença na chefatura de polícia:

Ilmo. sr. dr. Chefe de polícia. Os africanos abaixo assinados, sectários da religião maometana, requerem a V. S. permissão para se reunirem em casas particulares, sem forma exterior de templo, para exercerem os ofícios de sua religiáo, o que lhes parece ser facultado pelas leis do país, nestes termos pedem a V. S. deferimento e esperam receber mercê. Recife, 3 de dezembro de 1873. Sabino Antônio da Costa, a rogo de Joaquim Eugênio Maia. Anacleto Manuel dos Santos. S. Manoel Ribeiro Taques..$^{34}$

O africano Sírio Manoel Ribeiro Taques já foi apresentado neste texto. Porém, poucas informaçôes foram possíveis coletar sobre Sabino Antônio da Costa e Joaquim Eugênio Maia. Sabino era morador do bairro de Santo Antônio. Esteve também envolvido, profundamente, em conflitos com outros libertos, em 1877, por legitimidade de seus espaços

\footnotetext{
${ }^{34}$ PROTESTO contra o suposto culto maometano. Diario de Pernambuco, 28/08/1877 apud MELLO, J. A. G. de. Diario de Pernambuco: economia e sociedade no II Reinado. Recife: Edufpe, 1996, p. 95, (grifo nosso).
} 
religiosos, como mostraremos adiante. $\mathrm{O}$ fato de assinar o documento a rogo de Joaquim corrobora seu pertencimento à rede interreligiosa entre os confrades do Rosário e os sectários da religiāo maometana. Quanto a Joaquim, conseguimos apenas a informação de que ele residia à época no bairro de Sáo José.

Chamou-nos a atenção, contudo, a referência feita a Anacleto Manuel dos Santos. A princípio, pensamos ser ele também africano da Costa, mas ao garimpar seu nome em vários documentos, descobrimos que era crioulo e natural do Maranháo. Não foi possível, porém, saber como chegou ao Recife, se fora cativo ou viera para a província pernambucana já liberto. Era casado e exercia a ocupação de barbeiro, cujo ponto de trabalho, entre as décadas de 1860-1870, esteve em três endereços: rua Estreita do Rosário, n. 19; rua do Rangel, n. 19; e rua Visconde de Inhaúma. ${ }^{35}$ Ele foi também vizinho de bairro de Joaquim. Nas atas e compromissos do Rosário, Anacleto apareceu, como os demais já mencionados, ocupando cargos na mesa regedora. Em 1869, esteve junto com Estevão na Comissão Administrativa. Foi nomeado procurador do patrimônio na gestão de 1871-1872 e juiz em 1879. Em 1882, exerceu a função de tesoureiro por dois mandatos e encerrou sua carreira no cargo de definidor. ${ }^{36}$

Temos, então, lideranças muçulmanas, não só africanas, mas também brasileiras e, ainda, profundamente envolvidas em uma instituição católica! Joaquim Eugênio Maia, embora não pertencesse ao Rosário, comungava do catolicismo por meio das cerimônias de batismos. Não era incomum a comunidade negra transitar em duas culturas religiosas. No século XIX, viajantes europeus já registravam conexóes do islamismo com o catolicismo entre os africanos. Elizabeth Agassiz observou que, no Brasil, os homens minas conservavam "a sua crença no Profeta (Maomé), no meio das práticas da Igreja Católica”. ${ }^{37}$ Verger, a posteriori, mostrou as boas relaçôes de convivência entre muçulmanos e católicos nas comunidades de retornados em Uidá. O catolicismo serviu como elo entre os diferentes grupos de libertos que regressavam às cidades do golfo do Benin. Os muçulmanos que haviam retornado do Brasil, principalmente da Bahia, formavam um grupo à parte, encontrando-se muito mais próximos, pelos hábitos e modo de vida, dos católicos brasileiros do que dos próprios correligionários que permaneceram na África. ${ }^{38}$ No Recife,

\footnotetext{
${ }^{35}$ APEJE. Folhinhas de Algibeira. 1861a, fl. 313; 1861, fl. 264; 1862, fl. 282; 1864, fl. 283; 1873, fl. 202.

${ }^{36}$ IPHAN-PE, Livro de Atas (1879-1884), cx. 35, fls. 2-13, 14-19v, 23v, 44-45, 47, 59v e 87; Compromisso da Irmandade de N. S. do Rosário dos Pretos do Bairro de Santo Antônio, cx. 32, fl. 18v (página de assinaturas dos associados presentes à reunião). Arquivos da Matriz de São José (AMSJ), Assentamento de Óbito de Anacleto Manoel dos Santos, LO 23 (1886-1887), fl. 25v.

${ }^{37}$ Cf. AGASSIZ, Luiz; Elizabeth Cary. Viagem ao Brasil 1865-66. Brasília: Senado Federal, 2000, p. 102.

${ }^{38}$ Cf. VERGER, Pierre. Fluxo e refluxo: do tráfico de escravos entre o golfo do Benin e a Bahia de Todos os Santos, dos séculos XVII a XIX. 4. ed. rev. Salvador: Corrupio, 2002, p. 634-635. O pioneirismo nas investigaçóes sobre os africanos islamizados no Brasil deve-se a Nina Rodrigues. Ele narrou, a partir de sua convivência com os últimos africanos na Bahia (na virada do século XIX para o século XX), as experiências desses indivíduos como comunidade. Avaliando as revoltas escravas do início do século XIX, traçou seu perfil étnico e religioso, atribuindo aos haussás, tapas e iorubás, bem como ao islamismo, os fundamentos daquelas insurreiçóes. Para Rodrigues, todavia, existiu uma ortodoxia quanto à orientação religiosa das revoltas, sobretudo a de 1835. Cf. RODRIGUES, Nina. Os africanos no Brasil (1933). Disponível na Biblioteca Virtual de Ciências Humanas do Centro Edelstein de Pesquisas Sociais: <http://www.bvce.org/LivrosBrasileirosDetalhes.asp?IdRegistro=77>. Acesso em: 17 jul. 2015.
} 
a partir da década de 1870, os negros muçulmanos ganharam maior visibilidade, tornando-se notícia no Diario de Pernambuco. A recomposição das trajetórias, entrelaçadas, das pessoas que acompanhamos é parte do cenário desses trânsitos entre africanos católicos e islâmicos. ${ }^{39}$

$\mathrm{O}$ trânsito entre indivíduos islamizados e demais universos religiosos não se restringiu apenas à cultura católica. Houve uma circularidade ritual e simbólica também entre os cultos tradicionais africanos. Segundo Reis, foi possível a convivência pacífica entre muçulmanos, católicos e adeptos do culto de orixás. Ele identificou, em suas pesquisas para a Bahia de 1835, objetos como breves, papéis e tábuas com escritos em árabe, chocalhos de folha de flandres, que sugerem interconexôes entre a cultura muçulmana, a pagã e de outras religiôes. Essas circularidades e conexôes, para Reis, provavelmente já existiam desde a primeira metade do século XIX na África entre os indivíduos, sobretudo nagôs. Intensificaram-se, em momento posterior, quando os adeptos do culto de orixás reservariam também um espaço para as simbologias islâmicas em sua mitologia. ${ }^{40}$

Não obstante, apropriações e reelaborações de práticas e saberes muçulmanos, tais quais Reis identificou na Bahia oitocentista, também fizeram parte das experiências dos africanos no Recife. Disputas políticas entre dois grupos de africanos libertos pela representatividade maometana perante as autoridades policiais da província vislumbram conexóes entre o islamismo, o catolicismo e o xangô no Recife. ${ }^{41}$

Em 1877, após quatro anos do pedido dirigido à chefatura de polícia para a licença de prática do islamismo na cidade, no dia 21 de agosto foi publicado, no Diario de Pernambuco, um convite para os africanos residentes na cidade reunirem-se para o culto. No mesmo anúncio, pediam uma licença ao delegado da capital para praticar em suas casas, sem ofensas à moral pública, sua religião, dita por eles ser a maometana, pois tinham sido perturbados em São José pelo subdelegado, que os confundira com fetichistas e feiticeiros. O grupo, dessa vez, era formado por nove pessoas: Roberto Henrique Silvestre Machado, Frederico Inácio de Oliveira, Gregório Pereira da Cunha, Cassiano Antônio Vieira, Rufino Inácio de Oliveira, Pedro Salustiano Meuron, Jacinto Afonso da Costa e Joaquim Vieira da Silva. Este último era africano liberto, casado com a crioula baiana Izadora Maria da Conceiçấo. Joaquim Vieira ficou conhecido na tradição oral do candomblé, em Salvador e no Recife, como Obá Sanyá, e sua atuação foi relevante na fundação de importantes casas afrorreligiosas, como o Ilê Axé Iyá Nassô (a Casa Branca) em Salvador; e o Ilê Axé Iemanjá Ogunté (Sítio

\footnotetext{
${ }^{39}$ Ver ainda Mariza Soares e Priscila Mello que citam, en passant, informaçóes sobre africanos muçulmanos que, em 1915, se avizinhavam nos arredores da Igreja do Rosário em Penedo. Cf. SOARES, Mariza; MELLO, Priscila. "O resto perdeu-se?" História e folclore: o caso dos muçulmanos nas Alagoas. Disponível em: <www. ideario.org.br/wp/wp-content/uploads/2013/10/kule2-Mariza-e-Priscilla>. Acesso em: 7 set. 2016.

${ }^{40}$ Cf. REIS, João José. Rebeliáo escrava no Brasil: a história do levante dos malês em 1835, op. cit., p. 240-241.

${ }^{41} \mathrm{O}$ culto de orixás em Pernambuco recebe o nome de xangô. O termo, por sua vez, é polissêmico na região. Além de ser a religião de matriz africana, é também o local onde ocorre a liturgia (o terreiro), a própria festa pública (toque para orixás ou xirê).
} 
de Pai Adão) no Recife. ${ }^{42}$

Sete dias após o anúncio, no dia 28 de agosto, um segundo grupo protestou contra aquele pedido de licença para a prática islâmica. $\mathrm{O}$ grupo autor dessa nova publicação era formado por Sabino Antônio da Costa, Jovino Lopes Ferreira, Guilherme Manuel Pedro do Bom-fim, Pedro Joaquim Teixeira, Antônio Vieira, Sabino Patrício, José Victor de Oliveira, Daniel Rodrigues, José de Oliveira, João Estanislau, Bento Moncorvo e Luís Husque. Esse grupo, embora reconhecesse a diversidade dos africanos e as diferentes correntes do islamismo, acusava o primeiro de ser composto de falsos maometanos, pois já existia desde 1873 a licença policial para a prática daquela religião, não sendo necessária uma nova. ${ }^{43}$ Desse segundo grupo, além de Sabino Antônio da Costa e Jovino Lopes Ferreira, obtivemos informaçóes sobre Bento Moncorvo da Costa.

O africano Jovino Lopes Ferreira morava na freguesia de São José e era natural da Costa da Mina. Embora fosse solteiro, teve um casal de filhos: a crioula Joanna, com a também africana Rosa Maria da Conceição; e o crioulo Hilário, com a liberta Roza Germana. ${ }^{44}$ Também foi amigo particular e testamenteiro do "mina” Alexandre d'Almeida, cuja fortuna foi avaliada em 36:705\$840 réis, em 1880, soma bastante considerável até para brancos que nunca passaram pela experiência do cativeiro. Os filhos de Jovino chegaram também a ser legatários dessa fortuna, recebendo $100 \$ 00$ réis. Em maio de 1881, na qualidade de segundo testamenteiro, Jovino acusou a inventariante (Felisarda Maria da Conceição) e mãe da filha de Alexandre de má administradora do espólio e de negligenciar as últimas vontades do finado amigo. Segundo ele, Felisarda não tinha providenciado a construção do túmulo pedido por Alexandre em vida, estava fazendo despesas particulares para serem custeadas pelo patrimônio e negava-se a entregar os legados dos afilhados do africano. Além de acompanhar e cobrar judicialmente a inventariante de Alexandre, Jovino intercedeu por Evaristo, um dos afilhados do falecido amigo, que estava sendo prejudicado por Felisarda. ${ }^{45}$ Tudo indica que Jovino era influente no seio da comunidade africana, por isso também está entre os líderes do grupo que reivindicava a legitimidade de autênticos muçulmanos do Recife.

Bento Moncorvo da Costa, por sua vez, era natural da Costa d'África, de onde foi levado, na condição de cativo, para a Bahia, e dessa província para Pernambuco. Quando testou,

\footnotetext{
${ }^{42}$ AMSJ, Assento de casamento de Joaquim Vieira da Silva com Izidora (sic) Maria da Conceição, LC 4 (1878-1885), 31/01/1880, fl. 18v. Sobre a trajetória de Joaquim Vieira da Silva, consultar CASTILHO, Lisa. Entre a memória, mito e história: viajantes transatlânticos da Casa Branca. In: REIS, João José; AZEVEDO, Elciene (Org.). Escravidão e sombras. Salvador: Edufba, 2012, p. 65-110.

${ }^{43}$ AO PÚBLICO, 21/08/1877; PROTESTO contra os supostos do culto maometano, 28/08/1877, Diario de Pernambuco, apud MELLO, J. A. G. de. Diario de Pernambuco: economia e sociedade no II Reinado, op. cit., p. 93-95. João Reis, Flávio Gomes e Marcus Carvalho analisaram, na íntegra, esses anúncios em REIS, Joáo José; GOMES, Flávio dos Santos; CARVALHO, Marcus J. M. de. O alufá Rufino: escravidão, tráfico e liberdade no atlântico negro (1822 a 1853). São Paulo: Companhia das Letras, 2010, p. 337-354.

${ }^{44}$ AMSJ, Assento de batismo de Joanna crioula, fl. 11v; Assento de batismo do Hilário, crioulo, fl. 147v; LB 6 (1868-1874).

${ }^{45}$ Cf. COSTA, Valéria. Trajetórias negras: os libertos da Costa d'África no Recife, 1846-1890, op. cit., p. 150-151.
} 
no dia 12 de dezembro de 1890, estava doente e bastante endividado. Morador da rua dos Pescadores, n. 9, no bairro de Sáo José, declarou ser solteiro, mas pai de uma filha, Benedicta Maria da Conceição. Seu único bem era uma casa avaliada pelo próprio Bento em 2:500\$00, cujo solo era foreiro à Santa Casa de Misericórdia e estava em péssimo estado: cobertura, paredes e ladrilhos estragados. Mesmo assim, a referida casa encontrava-se hipotecada no valor de $450 \$ 000$ réis que contraiu com Emília Maria da Conceição para investimentos em seus negócios e tratamento de saúde. Ele também devia a Lucrécia Maria da Conceição 500\$000 réis, que tomou para completar o valor da compra de sua casa. ${ }^{46}$

Assim como a grande maioria dos africanos libertos, Bento, mesmo que tivesse conhecido algum sucesso financeiro, chegou ao fim de sua existência em condiçôes de precariedade: débitos, doença e praticamente sem teto. Este último, importante fator de afirmação do "viver sobre si" após a conquista da liberdade. Porém, nota-se que a grande conquista de liberdade de Bento estava quase em ruínas. A historiografia já demostrou o quanto era precária a liberdade dos ex-escravizados. Encontravam percalços para ingressar no mercado de trabalho livre e garantir sua sobrevivência. Constantemente, deviam provar sua nova condição: portando carta de alforria ou salvo-conduto, para circular a certas horas pelas ruas, dado por qualquer homem livre que estivesse disposto a abonar sua conduta. Os africanos enfrentavam uma dupla barreira: os estigmas do cativeiro e a condição de "estrangeiros indesejáveis". Para conseguir trabalho livre e ultrapassar os limites da sobrevivência, dependeriam das oportunidades que lhes fossem oferecidas pela sociedade escravista. ${ }^{47}$

A trajetória de Bento evidencia, ainda, as experiências de muçulmanos, na luta pela afirmação de espaço e legitimação de sua prática religiosa, no século XIX. Quando testou, informou que residia na província pernambucana "por superior a doze anos". Além do mais, nomeou como seu segundo testamenteiro Sabino Antônio da Costa, aquele muçulmano que encampou, em 1873, o pedido à chefatura de polícia para a prática do culto. ${ }^{48}$ Ou seja, é possível que Bento viesse morar no Recife, em meados da década de 1870, no início das divergências no meio da comunidade africana por legitimação de suas práticas religiosas. Suspeitamos, ainda, que ele viera de Salvador com o propósito de apoiar esses muçulmanos - autointitulados de autênticos islâmicos - acusando o grupo no qual estava Joaquim Vieira (Obá Sanyá) de falsos maometanos. A razão que levava Jovino Lopes e Bento Moncorvo a acusarem os demais africanos de "falsos" muçulmanos ou "supostos sectários do maometanismo" devia-se à existência de licença policial desde 1873, sendo desnecessária uma nova.

A década de 1870, ao que parece, não só foi marcada pela fragilização do sistema escravista, mas, sobretudo, por rivalidades na comunidade negra, que buscava legitimar sua con-

\footnotetext{
${ }^{46}$ IAHGP, Inventário (com testamento) de Bento Moncorvo da Costa, 1890, cx. 335, fl.2-3v.

${ }^{47}$ Cf. COSTA, Valéria. Trajetórias negras: os libertos da Costa d'África no Recife, 1846-1890, op. cit., p. 159.

${ }^{48}$ Cf. Inventário de Bento Moncorvo da Costa, fl. 3.
} 
dição de liberdade. ${ }^{49}$ Passadas as publicaçôes dos dias 21 e 28 de agosto de 1877, um grande confronto teve início entre esses dois grupos de africanos. Ressaltamos que, no meio desses muçulmanos, da década de 1870, não só havia africanos, mas também crioulos. Embora Anacleto Manoel seja o único crioulo que identificamos, nossa hipótese é que, por meio de novas pesquisas, cruzando os noticiários do $D P$ com outros documentos, haverá, possivelmente, outros crioulos entre os malês..$^{50}$

No $D P$, foram publicadas, além das notas de agosto, outras seis sobre as divergências entre os libertos, nas quais era perceptível não só a disputa pela legitimidade religiosa, como também o conhecimento da doutrina islâmica. O islamismo, ao contrário de outras religiôes africanas, aparecia no cenário de disputas entre os indivíduos porque se tornou uma religiáo tolerada abertamente pelos poderes políticos na província pernambucana. ${ }^{51}$ De um lado, o grupo "ilegítimo", buscando justificar sua aproximação com o catolicismo, argumentava que, no islamismo, mesmo sendo uma religião predominante na África, havia divisões entre os muçulmanos. Atacavam, contudo, o grupo de Jovino Lopes e Bento Moncorvo, acusando-o de "constrangerem as filhas de suas patrícias à poligamia, o que é contra as leis do país e a moral pública". 52

O grupo de Jovino Lopes e Bento Moncorvo, embora reconhecesse os vários ramos do islamismo, estranhava a ideia de aproximação com o catolicismo e as críticas feitas à poligamia. Segundo o referido grupo, a monogamia só teria se desenvolvido com o cristianismo, pois tanto os monoteístas árabes e hebreus quanto os politeístas africanos e asiáticos praticavam a poligamia. Ou seja, o argumento era deveras frágil para desqualificá-los. Alegaram ainda que o islamismo se dividia apenas em dois ramos, o dos sunitas (seguidores de Omar) e o dos xiitas (seguidores de Ali), e que em qualquer um desses ramos "se observa os preceitos da religião, sobretudo nos principais dogmas que os unificam, bem como a proibição de bebidas alcoólicas, o jejum no mês do Ramadâ, o banimento do culto de imagens, etc.". ${ }^{53}$ Os africanos do grupo de Joaquim Vieira, portanto, não poderiam ser islâmicos, pois adoravam imagens e faziam libaçôes com bebidas alcoólicas. Por fim, criticaram seus opositores, que haviam utilizado indevidamente o islamismo, dizendo: "a razão, porém, que vos levou a escolher para a vossa segurança o maometismo, foi por ser esta religião, segundo confessais em vossa explicação, a

\footnotetext{
${ }^{49}$ Chalhoub fez importante estudo sobre a precariedade da liberdade em $A$ força da escravidão: ilegalidade e costume no Brasil oitocentista. São Paulo: Companhia das Letras, 2012, p. 227-276.

${ }^{50}$ No registro de batismo do crioulo Joaquim, Sabino Antônio da Costa aparece como crioulo liberto. ACMRC, LB (1886), 10/6/1866, fl. 87.

${ }^{51}$ Cf. REIS, João José; GOMES, Flávio dos Santos; CARVALHO, Marcus J. M. de. O alufá Rufino, op. cit., p. 342.

${ }^{52}$ PUBLICAÇÓES a pedido, DP, 20/12/1877. In: MELLO, J. A. G. de. Diario de Pernambuco: economia e sociedade no II Reinado, op. cit., p. 102. Consultar sobre a prática da poligamia entre os africanos no Novo Mundo: THONRTON, John K. A África e os africanos na formação do mundo atlântico, 1400-1800. Rio de Janeiro: Elsevier, 2004, p. 139.

${ }^{53}$ AOS SUPOSTOS do maometismo, Publicações a Pedido, DP, 4/9/1877, apud Ibidem, p. 98.
} 
mais predominante na África." ${ }^{44}$ Isto é, a mais respeitada entre os próprios africanos.

Vale ressaltar que, implicitamente a essas disputas, estava a ideia de que a liberdade de culto deveria ser também para africanos adeptos de outras religióes de matriz africana, inclusive os seguidores do xangô. Em nenhum momento foi questionada pelos muçulmanos do grupo de Jovino e Bento a repressão policial ocorrida no dia 14 de agosto de 1877.55

Mas, não foi apenas na década de 1870 que apareceram notícias dos grupos islâmicos na cidade. Em 1815, uma rebelião de cativos africanos em Penedo (Alagoas) foi denunciada pelo ouvidor da Comarca ao governador e capitão geral de Pernambuco. Os revoltosos eram muçulmanos fugitivos da Bahia por ocasião das insurreições de $1807 .{ }^{56} \mathrm{Em} \mathrm{1865}$, o imã Abd al-Rahman al-Baghdádi visitou as cidades do Rio de Janeiro, Salvador e Recife. Nessas cidades, ele conheceu as comunidades muçulmanas e notou que os adeptos dessas capitais praticavam a religião de forma rude. Não sabiam recitar as sunas do Alcorão, ${ }^{57}$ desobedeciam o calendário islâmico, apegavam-se excessivamente aos amuletos, à adivinhação e a práticas consideradas pelo imã supersticiosas e inapropriadas. No Recife, porém, lhe chamou a atenção o fato de os maometanos serem mais aceitos do que nas outras cidades e da grande popularidade dos métodos de adivinhação entre as pessoas. Utilizavam a "geomancia", a "numerologia", os "quadrados mágicos" e faziam magia com as letras árabes. Todas essas técnicas eram disseminadas entre os islâmicos do oeste da África, em particular entre os iorubás. Segundo o imá, os muçulmanos faziam adivinhaçóes para ganhar a vida, tornando-se muito procurados, até mesmo, por brancos e mestiços, que buscavam seus serviços. O comportamento dos muçulmanos no Recife, segundo o imã, explicaria a existência de certa tolerância à religião na cidade. Tal tolerância pode ser avaliada a partir do cenário das publicaçóes das notas trocadas entre os dois grupos rivais. ${ }^{58}$

Não sabemos, contudo, sobre as experiências de todos os negros muçulmanos que vieram a público manifestar sua crença e brigar por seus espaços de culto. Mas aqueles cujos rastros seguimos, em alguns documentos, estabeleceram relaçóes com instituiçóes e indivíduos católicos. Jovino Lopes talvez não estivesse envolvido com o culto de orixás ou com o catolicismo. Difícil saber! Porém, não deixou de estabelecer laços de amizade com seus patrícios católicos, tampouco impediu sua família de participar de rituais cristãos. Nesse sentido, comentamos, alhures, o costume dele e de outros muçulmanos de levarem seus filhos para serem batizados na igreja. Quando batizou a crioula Joanna, sua filha, Jovino e a mãe da menina foram dados como solteiros. $\mathrm{O}$

\footnotetext{
${ }^{54}$ Ibidem, p. 99.

${ }^{55}$ Cf. REIS, João José; GOMES, Flávio dos Santos; CARVALHO, Marcus J. M. de. O alufá Rufino, op. cit. p. 348.

${ }^{56}$ Cf. SOARES, Mariza; MELLO, Priscila. “O resto perdeu-se?” História e folclore: o caso dos muçulmanos nas Alagoas, op. cit., p. 4-5.

${ }^{57}$ Conjunto de textos do Alcorão sobre costumes e obrigaçóes orientadores da vida e das açóes em sociedade, baseados nas práticas de Maomé.

${ }^{58}$ Cf. REIS, João José; GOMES, Flávio dos Santos; CARVALHO, Marcus J. M. de. O alufá Rufino: escravidão, tráfico e liberdade no atlântico negro (1822 a 1853), op. cit., p. 337 et seq. Para mais informaçóes sobre a visita do imã e análise mais detalhada das publicaçóes do $D P$ acerca das disputas entre os dois grupos de africanos libertos islamizados no Recife, consultar o capítulo 24 da citada obra.
} 
limite das fontes, por outro lado, impossibilitou-nos de saber se ele teria posteriormente se casado com a mãe de Joanna ou com a genitora de Hilário na igreja. Porém, Jovino náo foi o único muçulmano a batizar seus filhos. Os demais, que se consideravam verdadeiros malês, criaram extensas redes de compadrio por meio do sacramento católico. Sabino Antônio da Costa apadrinhou cinco crianças: o preto Adelino, os crioulos Joaquim e Manoel e as crioulas Monica e Joanna. Essa última, como já sabemos, era filha de seu compadre malê Jovino com a africana Rosa Maria da Conceição. Em 1876, um ano antes das disputas religiosas publicadas no DP, Sabino promoveu o batismo de Paulina, uma parda livre, filha de sua cativa Margarida..9 Joaquim Eugênio Maia, por sua vez, levou à pia batismal, no dia 25 de dezembro de 1876, a crioula Ceciliana. No dia 24 de setembro de 1877, momento dos conflitos dos muçulmanos com os praticantes do xangô, Joaquim levou seu filho, o crioulo Nicolau, para ser batizado. ${ }^{60}$ Já Anacleto Manoel dos Santos apadrinhou o crioulo Antônio, "forro pelo senhor", no dia 29 de junho de $1867 .{ }^{61}$ Como já sabemos, Sírio Manoel Ribeiro Taques era compadre de Jovino, por intermédio do batismo do crioulo Hilário. Além deste, ele foi padrinho de mais oito crianças: Ponâncio, Faustino, os irmãos Adolfo e Emília, Maria, Isadora, Ezequiel e Luiza. Por fim, Antônio José Vieira, integrante do grupo de Jovino, apadrinhou a parda Jovina, no dia 19 de dezembro de 1879, na Matriz de Santo Antônio. ${ }^{62}$

Essas redes de apadrinhamentos e compadrios mostram a intersecção religiosa entre africanos muçulmanos e católicos no Brasil. Para Verger, embora fossem o catolicismo e o islamismo religiôes intransigentes e exclusivas, os indivíduos transitavam em ambos os universos religiosos com equitativa sinceridade. Como ele frisou, esse foi um fenômeno erroneamente conceituado de sincretismo. ${ }^{63}$

\section{Considerações finais}

Como as fontes pesquisadas nos permitem considerar, as trajetórias de pessoas como $\mathrm{Sa}$ bino Antônio da Costa, Joaquim Eugênio Maia, Anacleto Manoel dos Santos, Sírio Manoel Ribeiro Taques e Jovino Lopes Ferreira revelam, para além das intersecçóes entre o catolicismo e o islamismo, disputas e negociaçóes — dentro e fora da comunidade negra — pela garantia de seus espaços político-sociais.

\footnotetext{
${ }^{59}$ AMSSBV, Assento de batismo de Adelino, 25/3/1883, LB 8 (1848-1854), fl. 120; ACMRO, Assento de batismo de Joaquim, 10/6/1866, LB 28 (1862-1872), fl. 87; assento de batismo de Monica, 11/9/1870, LB 6 (1868-1874), fl. 11; AMSJ, Assento de batismo de Joana, 22/07/1868, LB 6 (1868-1874), fl. 11v; Assento de batismo de Manoel, 24 jun. 1881, LB 9 (1879-1881), fl. 84v; Assento de batismo de Paulina, 2/4/1876, LB (1872-1890), fl. 11.

${ }^{60}$ AMSJ, Assento de batismo de Ceciliana, LB 5 (1863-1868), fl. [ilegível]; Assento de batismo de Nicolau, 24/9/1877, fl. [ilegível].

${ }^{61}$ AMSSSA, Assento de batismo de Antônio, LB (1863-1868), fl. 194.

${ }^{62}$ AMSSSA, Assento de batismo de Jovina, LB 22 (1871-1880), fl. 178.

${ }^{63}$ Cf. VERGER, Pierre. Os libertos: sete caminhos na liberdade de escravos da Bahia, no século XIX, op. cit., p. 40.
} 
O batismo católico, mais que uma conexão peculiar entre essas duas religióes, representava um documento importante para a afirmação da liberdade. Quem portava referido documento podia transitar nos espaços sociais e, quando tivesse sua condição questionada, apresentá-lo. Por sua vez, a ritualística desse sacramento significava a reconstrução de laços de parentescos que foram esgarçados pelo tráfico e pela escravização na diáspora. Laços parentais já existentes eram reforçados, relaçóes sociais eram solidificadas entre pessoas de classe semelhante ou, ainda, vínculos eram estabelecidos entre indivíduos de grupos desiguais. Os pais, comumente, escolhiam como padrinhos e madrinhas de seus filhos gente de prestígio no meio de sua comunidade ou em outros espaços da cidade. Essas alianças familiares constituíam-se em sociabilidades importantes para todos os envolvidos, nas quais eram cultivadas relaçóes de clientelismo, em que náo só se privilegiavam concessóes de favores de cima para baixo, mas também promessas recíprocas de serviços, obediência, deferência e lealdade. Para Solange Rocha, o compadrio representava ainda mudança de vida para as pessoas de cor preta. Os forros, muitas vezes, estavam interessados em se fixar no universo dos nascidos livres, ou buscavam meios para suas sobrevivências. Já os escravizados empenhavam-se na busca de possibilidades futuras para a conquista da liberdade ou até na criação de circunstâncias favoráveis para viver nas suas condições, vistas pela sociedade como as mais desprestigiadas. ${ }^{64}$ Tudo isso, certamente, justifica as motivaçóes dos maometanos, como os aqui descritos, a participarem do ritual católico.

Outros elementos, como a água, comuns ao catolicismo e ao islamismo, apresentam-se como peças para compor o quebra-cabeças dessas conexóes entre os indivíduos, que compartilham de ambos os universos culturais. Elemento vital, símbolo de pureza e purificação do corpo, a água está presente dos rituais da vida às cerimônias fúnebres. Nas igrejas e nas mesquitas há pias batismais e fontes de água. Os muçulmanos comumente fazem abluçóes antes de cada uma das cinco oraçóes diárias, lavando cabeça, máos, antebraços e pés. No ritual fúnebre, o morto é banhado três vezes antes de receber pó de cânfora nos pontos de prostração. Os católicos usam água em momentos solenes, como no batismo e nas missas festivas, quando são feitas aspersóes de água benta nos fiéis.

Essas conexóes interreligiosas, ademais, revelam também sociabilidades, não excludentes de tensóes pelo poder dentro e fora da comunidade escrava e africana. Identidades foram sendo recriadas, ora pautadas no passado africano, ora na experiência do cativeiro, ora, ainda, a partir dos novos projetos de parcerias depois da manumissão. Ou seja, estabelecimentos de laços familiares, parentescos, trabalho. Por fim, esses diálogos político-religiosos podem também ser encarados como movimentos da diáspora, no qual identidades étnicas, naçóes ou procedências eram negociadas, paulatinamente, na sociedade escravista; sendo, pois, reconfiguradas no período pós-emancipação.

\footnotetext{
${ }^{64}$ Cf. COSTA, Valéria. Trajetórias negras: os libertos da Costa d'África no Recife, 1846-1890, op. cit., p. 144145; ROCHA, S. Gente negra na Paraíba oitocentista: população, família e parentesco espiritual. São Paulo: Unesp, 2009, p. 221-223.
} 


\section{Referências bibliográficas}

AGASSIZ, Luiz; Elizabeth Cary. Viagem ao Brasil 1865-66. Brasília: Senado Federal, 2000. ALBUQUERQUE, Wlamyra. O jogo da dissimulação: abolição e cidadania negra no Brasil. São Paulo: Companhia das Letras, 2009.

AMARAL, Sharise Piroupo do. Um pé calçado e outro no chão: liberdade e escravidáo em Sergipe (Continguiba, 1860-1890). Salvador: Edufba, 2012.

ARAÚJO, Clara. Governadores das naçôes e das corporaçôes: cultura política e hierarquias de cor em Pernambuco (1776-1817). Dissertação (mestrado em História) — Universidade Federal Fluminense, Niterói, 2007.

ASSIS, Virgínea M. Almoêdo de. Pretos e brancos: a serviço de uma identidade de dominação (o caso das irmandades do Recife). Dissertação (mestrado em História) - Universidade Federal de Pernambuco, Recife, 1998.

CALAINHO, Daniela. Metrópole das mandingas: religiosidade negra e inquisição portuguesa no Antigo Regime. Rio de Janeiro: Garamond, 2008.

CASTILHO, Lisa. Entre a memória, mito e história: viajantes transatlânticos da Casa Branca. In: REIS, João José; AZEVEDO, Elciene (Org.). Escravidão e sombras. Salvador: Edufba, 2012.

CHALHOUB, Sidney. A força da escravidão: ilegalidade e costume no Brasil oitocentista. São Paulo: Companhia das Letras, 2012.

. Visóes da liberdade: as últimas décadas da escravidão na corte. São Paulo: Companhia da Letras, 1990.

COSTA, Valéria. Trajetórias negras: os libertos da Costa d'África no Recife, 1846-1890. Tese (doutorado em História Social) — Universidade Federal da Bahia, Salvador, 2013.

DELFINO, Leonarda Lacerda. O rosário dos irmãos escravos e libertos: fronteiras, identidades e representaçóes do viver e morrer na diáspora atlântica. Tese (doutorado em História) Universidade Federal de Juiz de Fora, Juiz de Fora, 2015.

FARIAS, Juliana Barreto. Mercados minas: africanos ocidentais nas praças do Rio de Janeiro (1830-1890). Tese (doutorado em História Social) — Universidade de Sáo Paulo, Sáo Paulo, 2012.

GUERRA PEIXE, Cesar. Maracatus do Recife. Recife: Prefeitura da Cidade do Recife, 1980. GINZBURG, Carlo. Mitos, emblemas e sinais. Morfologia e história. São Paulo: Companhia das Letras, 1989.

LEVI, Giovani. A herança imaterial: trajetória de um exorcista no Piemonte do século XVII. Rio de Janeiro: Civilização Brasileira, 2000. 
MAC CORD, Marcelo. O rosário de D. Antônio: irmandades negras, alianças e conflitos na história social do Recife, 1848-1872. Recife: Edufpe, 2008.

MELLO, José A. Gonsalves de. Diario de Pernambuco: economia e sociedade no II Reinado. Recife: Edufpe, 1996.

OLIVEIRA, Maria Inês Côrtes de. O liberto: seu mundo e os outros (1790-1890), Salvador: Corrupio, 1988.

PARÉS, Nicolau Luís. Milicianos, barbeiros numa irmandade católica de africanos minas e jejes (Bahia, 1770-1830), Tempo, Rio de Janeiro, v. 20, p. 1-32, 2014.

QUINTÁO, Antônia. Lá vem meu parente: as irmandades de pretos e pardos no Rio de Janeiro e em Pernambuco (século XVIII). São Paulo: Annablume, 2002.

REGINALDO, Lucilene. Os rosários dos angolas: irmandades de africanos e crioulos na Bahia setecentista. São Paulo: Alameda, 2011.

REIS, João; GOMES, Flávio; CARVALHO, Marcus. O alufá Rufino: escravidão, tráfico e liberdade no atlântico negro (1822 a 1853). São Paulo: Companhia das Letras, 2010.

REIS, João. Rebelião escrava no Brasil: a história do levante dos malês em 1835. Ed. rev. e ampl. São Paulo: Companhia das Letras, 2003.

- A morte é uma festa: ritos fúnebres e revolta popular no Brasil no século XIX. São Paulo: Companhia das Letras, 1991.

. Identidade e diversidade étnica nas irmandades negras no tempo da escravidão, Tempo, Rio de Janeiro, v. 2, n. 3, p. 199-242, 1997.

ROCHA, Solange. Gente negra na Paraíba oitocentista: população, família e parentesco espiritual. São Paulo: Unesp, 2009.

RODRIGUES, Cláudia. Lugares dos mortos na cidade dos vivos: tradições e transformações fúnebres no Rio de Janeiro. Rio de Janeiro: Secretaria Municipal de Cultura, 1999.

RODRIGUES, Nina. Os africanos no Brasil (1933). Disponível na Biblioteca Virtual de Ciências Humanas do Centro Edelstein de Pesquisas Sociais: <http://www.bvce.org/ LivrosBrasileirosDetalhes.asp?IdRegistro=77>. Acesso em: 17 jul. 2015.

SIAL, Vanessa. Das igrejas ao cemitério: políticas públicas sobre a morte no Recife no século XIX. Recife: Fundação de Cultura Cidade do Recife, 2007.

SCHANTZ, Ana Paula. Libertos no Rio Grande de São Pedro: Porto Alegre e Viamão no final do século XVIII e início do XIX. Dissertação (mestrado em História) — Universidade Federal da Bahia, Salvador, 2009.

SOARES, Mariza. Devotos da cor. In: MAC CORD, Marcelo. O rosário de D. Antônio: irmandades negras, alianças e conflitos na história social do Recife 1848-1872. Recife: Edufpe, 2008.

. Devotos da cor: identidade étnica, religiosidade e escravidão no Rio de Janeiro, 
século XVIII. Rio de Janeiro: Civilização Brasileira, 2000.

SOARES, Mariza; MELLO, Priscila. "O resto perdeu-se?" História e folclore: o caso dos muçulmanos nas Alagoas. Disponível em: <www.ideario.org.br/wp/wp-content/ uploads/2013/10/kule2-Mariza-e-Priscilla>. Acesso em: 7 set. 2016.

THONRTON, John. A África e os africanos na formação do mundo atlântico, 1400-1800. Rio de Janeiro: Elsevier, 2004.

VERGER, Pierre. Fluxo e refluxo: do tráfico de escravos entre o golfo do Benin e a Bahia de Todos os Santos, dos séculos XVII a XIX. 4. ed. rev. Salvador: Corrupio, 2002.

. Os libertos: sete caminhos na liberdade de escravos da Bahia, no século XIX. Salvador: Corrupio, 1992.

XAVIER, Regina Célia. Religiosidade e escravidão no século XIX: mestre Tito. Porto Alegre: Editora da UFRGS, 2008.

\section{Como citar}

COSTA, Valéria Gomes. Irmãos do Rosário e sectários da religião maometana: sociabilidades entre africanos no Recife oitocentista. Topoi. Revista de História, Rio de Janeiro, v. 19, n. 37, p. 33-56, jan./abr. 2018. Disponível em: <www.revistatopoi.org>.

\section{Errata}

DOI da errata: 10.1590/2237-101X01903713

No artigo: Irmãos do Rosário e sectários da religião maometana: sociabilidades entre africanos no Recife oitocentista", com número de DOI: http://dx.doi.org/10.1590/2237-101x0193702, publicado no periódico Topoi. Revista de História, v. 19, n. 37, jan./abr. 2018, p. 33-53, nas páginas 48 (nota 43), 50 (nota 51), e 51 (notas 55 e 58):

\section{Onde se lia:}

REIS, João José; GOMES, Flávio dos Santos; CARVALHO, José Murilo de. O alufá Rufino: escravidão, tráfico e liberdade no atlântico negro (1822 a 1853).

\section{Leia-se:}

REIS, João José; GOMES, Flávio dos Santos; CARVALHO, Marcus J. M. de. O alufá Rufino: escravidão, tráfico e liberdade no atlântico negro (1822 a 1853).

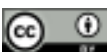

